\title{
Pengaruh Waktu Pemberian Ekstrak Etanol 70\% Daun Sirsak (Annona muricata L.) Terhadap Kadar Glukosa Darah Mencit (Mus musculus) Yang Diinduksi High Fat Diet Dan PTU
}

\author{
Andy Susbandiyah Ifada ${ }^{\text {a, } 1 *}$, Rida Amelia ${ }^{\text {a, }}$, Dahlia Andayani ${ }^{\text {a, } 3}$ \\ Program Studi Farmasi, Fakultas Ilmu Kesehatan, UNW Mataram, Mataram, NTB, Indonesia \\ 'diyah.ifada@gmail.com \\ "korespondensi penulis
}

\begin{tabular}{|c|c|}
\hline INFO ARTIKEL & ABSTRAK \\
\hline $\begin{array}{l}\text { Diterima : } \\
\text { II-OI-202I } \\
\text { Disetujui : } \\
\text { I9-0I-202I }\end{array}$ & $\begin{array}{l}\text { Perubahan pola makan menjadi tinggi lemak dan gula menyebabkan munculnya } \\
\text { banyak masalah, salah satunya obesitas yang menjadi faktor resiko Diabetes Melitus } \\
\text { tipe } 2 \text {. Upaya pencegahan dan pengobatan dengan bahan alam menjadi pilihan, salah } \\
\text { satunya dengan daun sirsak. Tujuan penelitian adalah untuk mengetahui adakah } \\
\text { pengaruh waktu pemberian ekstrak etanol } 70 \% \text { daun sirsak (annona muricata } \mathrm{L} \text { ) }\end{array}$ \\
\hline $\begin{array}{l}\text { Kata kunci: } \\
\text { High Fat Diet; } \\
\text { Glukosa Darah; } \\
\text { Ekstrak etanol daun } \\
\text { sirsak }\end{array}$ & 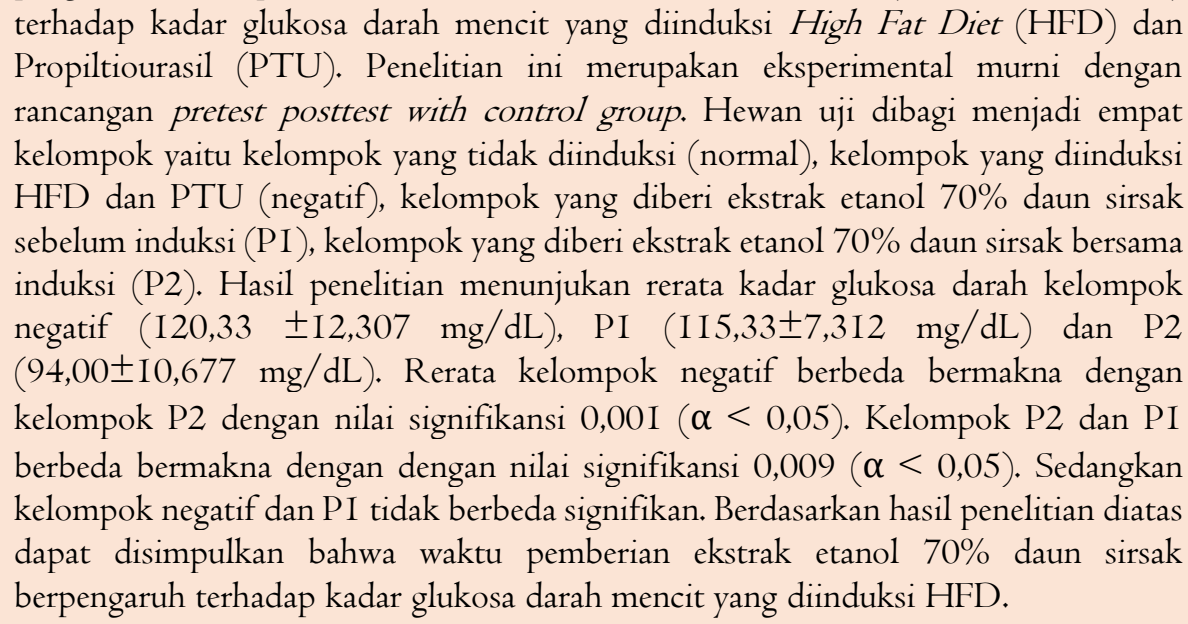 \\
\hline
\end{tabular}

Key word:

High Fat Diet;

Blood Glucose;

Ethanol extract of

soursop leaves.

\section{ABSTRACT}

Changes in diet to be high fat and sugar cause many problems, one of them is obesity which is a risk factor for Type 2 Diabetes Mellitus. Prevention and treatment with natural ingredients is an option, one of which is soursop leaves. The aim of the study was to determine whether the time of administration of ethanol extract $70 \%$ soursop leaves (Annona muricata L.) had an effect on blood glucose levels of mice induced by High Fat Diet (HFD) and Propyltiouracil (PTU). This research is a pure experimental study with a pretest posttest with control group design. The animals were divided into four groups: the group that was not induced (normal), the group that was induced by HFD and PTU (negative), the group given $70 \%$ ethanol extract of soursop leaves before induction (PI), the group given $70 \%$ ethanol extract of soursop leaves while induction (P2). The result showed that average of blood glucose levels in the group negative control (I20.33 $\pm 12.307 \mathrm{mg} / \mathrm{dL}$ ), PI (II5.33 \pm 7.312 $\mathrm{mg} / \mathrm{dL})$ and P2 $(94.00 \pm 10.677 \mathrm{mg} / \mathrm{dL})$. The mean of the negative group was significantly different from the P2 group with a significance value of 0.00I ( $\alpha$ $<0.05)$. Group P2 and PI differed significantly with a significance value of $0.009(\alpha$ $<0.05$ ). Meanwhile, the negative group and PI did not differ significantly. It can be concluded that the time of administration of $70 \%$ ethanol extract of soursop leaves affects the blood glucose levels of mice that are induced by HFD and PTU.

This is an open access article under the CC-BY-SA license. 


\section{Pendahuluan}

Diet kaya kalori, garam, lemak jenuh, gula, dan konsumsi rendah serat dapat menyebabkan peningkatan berat badan berlebih yang kemudian dapat meningkatkan risiko Diabetes Melitus tipe 2. Hasil survei Kemneterian Kesehatan menunjukkan bahwa rata - rata konsumsi gula masyarakat Indonesia sebesar I4,2 gram, garam 3,6 gram, dan minyak 20,6 gram. Konsumsi gula tertinggi berada di Provinsi Daerah Istimewa Yogyakarta, konsumsi garam tertinggi di Provinsi Nusa Tenggara Barat, dan konsumsi minyak tertinggi di DKI Jakarta. Kejadian ini diduga sebagai penyebab terus meningkatnya prevalensinya penyakit Diabetes Melitus tipe 2 termasuk di Indonesia sehingga dapat menyebabkan kerugian ekonomi yang besar bagi penyandang Diabetes, keluarga mereka, dan Negara.

Data International Diabetes Federation tahun 2017, prevalensi Diabetes Melitus di dunia mencapai sekitar 425 juta penderita (I dari I I penduduk dunia) dan sekitar 10 juta penderita tersebut terdapat di Indonesia. Dari total tersebut, $90 \%$ penderita merupakan kasus DM tipe 2 dan setengah dari total tersebut merupakan penderita yang tidak terdiagnosa (IDF, 20I7). Fakta bahwa perkembangan dari obesitas dan resistensi insulin menjadi DM Tipe 2 membutuhkan waktu yang lama, menjadikan peluang yang baik untuk terapi pencegahan (preventif) bagi penyakit ini.

Berlimpahnya tanaman obat di Indonesia menjadi kesempatan untuk mencari tanaman untuk pengobatan maupun pencegahan. Salah satu tanaman yang telah banyak diteliti dapat menurunkan kadar glukosa darah adalah sirsak (Annona muricata L). Penelitian Setyawati, dkk., pada 2015 menyatakan ekstrak etanol $70 \%$ daun Sirsak dapat menurunkan kadar glukosa darah pada tikus galur wistar yang diinduksi aloksan. Selain sebagai antihiperglikemia, ekstrak air daun Sirsak juga dapat menurunkan obesitas atau mengendalikan bobot badan dan menurunkan kolesterol pada tikus wistar (Yuniarti, dkk, 20I6).

Di wilayah Lombok, daun sirsak sampai saat ini belum banyak dipergunakan sebagai alternatif pengobatan maupun pencegahan padahal daun sirsak (Annona muricata L.) memiliki beberapa manfaat yang menjadikannya sangat mungkin untuk dijadikan kandidat terapi pencegahan pada resistensi insulin dan bahkan Diabetes Melitus tipe 2. Tujuan penelitian ini untuk melihat pengaruh waktu pemberian esktrak etanol daun sirsak terhadap kadar glukosa darah mencit yang diinduksi High Fat Diet (HFD) dan Propiltiourasil (PTU) sehingga diharapkan dapat menjadi agen pencegahan terjadinya diabetes mellitus khususnya akibat obesitas dan resistensi insulin .

\section{Metode}

Penelitian ini bersifat eksperimen sungguhan (true experiment) dengan rancangan Pretest - posttest with control group.

\section{Alat dan Bahan}

Batang pengaduk, beaker glass, cawan porselen, erlenmeyer, gelas ukur, glukometer, kandang hewan, labu ukur, needle $27 \mathrm{G}$, pipet tetes, restrainer mencit, rotary evaporator, sonde oral, timbangan analitik, timbangan hewan.

Aquadest, daun sirsak, etanol 70\%, kuning telur, mentega, minyak kelapa, propiltiourasil (PTU), strip test glukosa.

\section{Pengolahan Sampel}

Daun sirsak berasal dari Desa Bangket Dalem Kecamatan Kediri Lombok Barat. Daun yang digunakan adalah daun ketiga dari pucuk. Sebanyak 500 gram daun sirsak dibersihkan dengan cara dicuci dengan air mengalir, dikeringkan dengan cara dianginanginkan kemudian dirajang menjadi ukuran yang lebih kecil.

\section{Pembuatan Ekstrak Etanol Daun Sirsak (EEDS)}

Simplisia daun sirsak (Annona muricata L) diekstraksi dengan teknik maserasi. Maserasi dilakukan dengan memasukkan daun sirsak kering bobot II8 gram ke dalam bejana dan ditambahkan pelarut etanol $70 \%$ sampai simplisia terendam.

Volume etanol 70\% $1.500 \mathrm{~mL}$. Bejana maserasi dilapisi dengan aluminium foil dan ditutup. Disimpan pada suhu ruangan selama 7 hari dengan pengadukan setiap hari selama I5 menit. Hasil maserasi kemudian disaring dan diuapkan menggunakan rotary evaporator sampai didapatkan ekstrak kental.

\section{Persiapan Hewan Uji}

Hewan uji yang digunakan adalah mencit sehat dan memperlihatkan aktivitas normal, bobot badan 20 - 30 gram. Jumlah mencit yang disiapkan adalah 24 ekor dan dibagi dalam 4 kelompok. Sebelum penelitian, mencit diadaptasikan selama 5 hari dalam kandang pada suhu ruangan dan pakan serta minuman standar.

\section{Persiapan Induksi High Fat Diet (HFD)+ PTU}

High Fat Diet (HFD) untuk induksi resistensi insulin pada tikus menggunakan dari lemak sebesar 60\%. (Mosser \& Maulis, 2015). Pada penelitian ini dilakukan memodifikasi jenis pakan yang diberikan yaitu jagung 40\%, lemak sapi 30\%, minyak kelapa 12\%, mentega 15\% dan kunig telur 3\%. PTU 0,26 $\mathrm{mg} / 20 \mathrm{~g}$ BB disuspensikan dalam $50 \mathrm{ml} \mathrm{Na-CMC}$ $0,3 \%$. 
Perlakuan High Fat Diet (HFD) + PTU dan pengukuran kadar glukosa darah

Mencit dikelompokkan menjadi 4 kelompok masing-masing kelompok normal, kontrol negatif, perlakuan I (pemberian EEDS sebelum induksi HFD+PTU), dan perlakuan 2 (pemberian EEDS bersamaan dengan induksi HFD+PTU). Semua mencit dipuasakan selama I2 jam kemudian dilakukan pengukuran kadar glukosa darah puasa awal. Pada minggu pertama semua kelompok diberi pakan standar dan minum aquadest. Kelompok normal, kontrol negatif dan perlakuan 2 seterusnya selama 7 hari tetap diberi aqudest sedangkan kelompok perlakuan I diberi EEDS $200 \mathrm{mg} / \mathrm{Kg} \mathrm{BB}$ secara per oral setiap hari. Pada akhir minggu pertama dilakukan pengukuran kadar glukosa darah puasa. Minggu ke-2 kelompok normal tetap diberi pakan standar dan minum aqudest sedangkan kelompok kontrol negatif, perlakuan I dan perlakuan 2 diberi induksi HFD + PTU setiap hari .

Pemberian EEDS $200 \mathrm{mg} / \mathrm{Kg} \mathrm{BB}$ secara per oral dilakukan pada kelompok perlakuan 2. Pada akhir minggu ke-2 kembali dilakukan pengukuran kadar glukosa darah puasa. Induksi HFD+PTU per oral dilakuan secara teratur setiap hari selama 7 hari pada jam yang sama. Pengukuran glukosa darah dilakukan secara cepat menggunakan strip test glukometer Easytouch $^{\circledR}$ dengan menggunakan sampel darah dari vena ekor mencit.

\section{Analisis Data}

Data yang didapatkan diolah secara statistik dengan menggunakan SPSS 17.0.

\section{Hasil dan Pembahasan}

Ekstraksi

Dari ekstraksi II8 gram simplisia daun sirsak menggunakan $1.500 \mathrm{~mL}$ etanol $70 \%$ diperoleh 13 gram ekstrak kental berwarna hitam kecoklatan dan berbau khas dengan nilai rendemen ekstrak II\%.

\section{Pengukuran Kadar Glukosa Darah Puasa}

Pengukuran kadar glukosa darah puasa dilakukan pada awal penelitian (baseline), pada minggu pertama setelah pemberian EEDS (Week I = WI) dan terakhir pada minggu kedua (Week $2=W 2$ ) yaitu setelah pemberian EEDS bersamaan dengan induksi High fat Diet (HFD) + PTU. Hasil pengukuran dapat dilihat pada tabel I :
Tabel I Hasil Rerata Kadar Glukosa Darah

\begin{tabular}{|c|c|c|c|c|}
\hline \multirow[t]{2}{*}{ Kelompok } & \multirow[t]{2}{*}{$\mathrm{n}$} & \multicolumn{3}{|c|}{$\begin{array}{l}\text { Rerata Kadar Glukosa Darah } \\
\text { Puasa } \pm \mathrm{SD}(\mathrm{mg} / \mathrm{dL})\end{array}$} \\
\hline & & Awal & WI & W2 \\
\hline $\begin{array}{c}\text { Norm } \\
\text { al }\end{array}$ & 6 & $\begin{array}{l}96,00 \pm \\
10,000\end{array}$ & $\begin{array}{c}97,17 \\
\pm 9,57 \\
9\end{array}$ & $\begin{array}{l}99,83 \\
\pm \\
7,859\end{array}$ \\
\hline$\underset{f}{\text { Negati }}$ & 6 & $\begin{array}{l}99,33 \pm \\
10,558\end{array}$ & $\begin{array}{c}97,17 \\
\pm 7,80 \\
8\end{array}$ & $\begin{array}{l}120,33 \pm \\
12,307\end{array}$ \\
\hline PI & 6 & $\begin{array}{c}97,33 \pm \\
6,377\end{array}$ & $\begin{array}{c}98,83 \\
\pm 8,03 \\
5\end{array}$ & $\begin{array}{l}\text { II } 5,33 \pm \\
7,312\end{array}$ \\
\hline $\mathrm{P} 2$ & 6 & $\begin{array}{c}94,67 \pm \\
6,563\end{array}$ & $\begin{array}{c}94,40 \\
\pm 6,34 \\
8\end{array}$ & $\begin{array}{l}94,00 \pm \\
10,677\end{array}$ \\
\hline
\end{tabular}

Keterangan : Normal (Kelompok yang tidak diinduksi HFD dan PTU), Negatif (Kelompok yang diinduksi HFD dan PTU), PI (Kelompok yang diberi EEDS sebelum induksi), P2 (Kelompok yang diberi EEDS bersamaan dengan induksi)

Rerata kadar glukosa darah awal memperlihatkan nilai baseline yang berada dalam rentang nilai normal glukosa darah puasa $(<\mathrm{IIO} \mathrm{mg} / \mathrm{dL})$. Pengukuran minggu pertama (tanpa induksi HFD+PTU) tidak memperlihatkan peningkatan kadar glukosa darah puasa di atas $110 \mathrm{mg} / \mathrm{dL}$. Minggu kedua memperlihatkan peningkatan terutama pada kadar glukosa darah kelompok negatif dan PI. Sementara pada kelompok normal dan pada P2 masih berada dalam nilai normal. Hal ini menunjukkan bahwa pemberian ekstrak daun sirsak bersamaan dengan induksi HFD+PTU memberikan pengaruh pada peningkatan kadar glukosa darah.

Analisis data dilakukan dengan menggunakan uji one way anova dengan nilai sigifikansi $<0,05$. Hasil menunjukkan nilai signifikansi pada pengukuran awal sebesar 0,809 atau $>0,05$. Artinya, tidak terdapat perbedaan bermakna pada kadar glukosa awal dari keempat kelompok mencit. Hal ini sesuai dengan harapan karena pada minggu tersebut mencit belum diberi perlakuan dan induksi apapun. Pada WI nilai signikansi 0,842 yang artinya pada WI juga tidak terdapat perbedaan bermakna pada kadar glukosa darah puasa antar kelompok. Hal ini menunjukkan pemberian EEDS tidak memberikan pengaruh pada glukosa darah mencit sebelum diinduksi HFD+PTU. Pada W2 nilai signifikansi yang didapatkan 0,00I, lebih kecil dari 0,05 yang menunjukkan adanya perbedaan antara keempat kelompok.

Uji post hoc menggunakan Tukey dilakukan pada data glukosa darah W2 di mana diperoleh hasil kelompok normal berbeda bermakna dengan kelompok 
negatif dengan nilai signifikansi $0,008(<0,05)$ artinya rerata kadar glukosa darah kelompok normal berbeda dari kelompok negatif. Hal ini menunjukkan bahwa pemberian HFD dapat meningkatkan kadar glukosa darah mencit. Kelompok negatif berbeda bermakna dengan kelompok P2 dengan nilai signifikansi 0,00I atau $<0,05$ yang menunjukkan bahwa rerata kadar glukosa darah kelompok negatif lebih tinggi dari kelompok P2. Hal ini menunjukkan bahwa pemberian ekstrak etanol bersamaan dengan induksi HFD mempengaruhi kadar glukosa darah.

Sedangkan untuk kelompok PI terlihat tidak menunjukkan perbedaan yang bermakna dengan kelompok kontrol negatif (nilai signifikansi 0,809 > 0,05). Hal ini menunjukkan bahwa pemberian ekstrak etanol daun sirsak sebelum induksi tidak memberikan pengaruh terhadap peningkatan kadar glukosa darah akibat induksi HFD+PTU. Antara perlakuan I (PI) dan perlakuan 2 (P2) menunjukkan hasil yang berbeda bermakna dengan nilai signifikansi 0,009 $(<0,05)$. Kedua perlakuan ini memberikan pengaruh yang berbeda terhadap kadar glukosa darah hewan uji yang diinduksi HFD+PTU.

\section{Simpulan dan Saran}

Pemberian ekstrak etanol $70 \%$ daun sirsak (EEDS $200 \mathrm{mg} / \mathrm{Kb} \mathrm{BB}$ ) pada mencit sebelum dan bersamaan dengan induksi High Fat Diet + PTU berpengaruh terhadap kadar glukosa darah. Pemberian EEDS secara bersamaan dengan waktu induksi memperlihatkan nilai glukosa darah yang normal.

Disarankan untuk melakukan analisis komponen senyawa yang berkhasiat pada ekstrak etanol $70 \%$ daun sirsak serta perlu penambahan waktu induksi karena pada kenyataannya konsumsi lemak tinggi di masyarakat berlangsung bertahun-tahun sebelum menyebabkan diabetes melitus tipe 2 .

\section{Daftar Pustaka}

Heydemann, A., (2016). An Overview of Murine High Fat Diet as a Model for Type 2 Diabetes Mellitus. Journal of Diabetes Research, pp. II4.

Internasional Diabetes Federation (IDF), (20I7). DIABETES ATLAS - 8 TH EDITION. Retrieved from http://www.diabetesatlas.org/

Kementerian Kesehatan RI., (2015). Studi Diet Total : Potret Pola Makan Penduduk Indonesia Saat Ini. Retrieved from http://www.depkes.go.id/article/view/I504 I400003/studi-diet-total-potret-pola-makanpenduduk-indonesia-saat-ini.html

Khitan, Z. \& Kim, D. H., (2013). Fructose: A Key Factor in the Development of Metabolic
Syndrome and Hypertension. Hindawi : Journal of Nutrition and Metabolism, pp. II2.

Malole \& Paramono, (1989). Penggunaan Hewan Hewan Percobaan di Laboratorium. Bogor: Institut Pertanian Bogor.

Marjoni, M. R., (2016). Dasar - Dasar Fitokimia Untuk Diploma III Farmasi. Jakarta: Trans Info Media

Mosser, R. E. \& Maulis, M. F.. (2015). High-fat dietinduced beta-cell proliferation occurs prior to insulin resistance in C57BI/6J male mice. Am J Physiol Endocrinol Metab, p. E573-E582.

Setyawati, t., Nurjannah \& Azam, A., (2015). Manfaat Ekstrak Daun Sirsak (Annona muricata) Sebagai Antihiperglikemia Pada Tikus Wistar Diabetik yang Diinduksi Aloksan. Jurnal Ilmiah Kedokteran volume 2, pp. 19-30.

Sun, C., Li, X. \& Li, L., (2016). Effect of Fasting Time on Measuring Mouse Blood Glucose Level. pp. 4I86-4I89.

Yuniarti, L., Dewi, M. K., Lantika, U. A. \& Bhatara, T., (2016). Potensi Ekstrak Air Daun Sirsak Sebagai Penurun Kolesterol dan Pengendali Bobot Badan. Acta Veterinaria Indonesia volume 4 No.2, pp. 82-87 